\title{
PSYCHE
}

\begin{tabular}{lll}
\hline Vol. 66 & December, 1959 & No. 4 \\
\hline
\end{tabular}

\section{WILLIAM M. MANN}

"Each day I would stroll along the beach to a new stream and follow it to a new part of the forest, in a continual state of exultation over the abundant and interesting specimens."

\section{Ant Hill Odyssey}

The intense enthusiasm with which William Mann undertook the exploration of remote insect faunas was the dominant note in his unusual and distinguished scientific career. As a young man embarking on a series of extensive collecting trips to Brazil, Mexico, the West Indies, the Middle East, the South Pacific, and other parts of the world, he openly sought personal adventure as a major reward of scientific endeavor. The "Ant Hill Odyssey", as he later signified it in the title of his autobiography, was never allowed to stagnate in the physical confinement and routine that sometimes make scholarly enterprise falsely seem less than a great adventure. This spirit he was able to transmit to younger entomologists, and it was responsible for the beginning of the career of more than one young field biologist.

There would be little gain in attempting to recall here the events of Mann's crowded life already told so vividly in his autobiography. It may be noted that most of his entomological field work was conducted while he was a graduate student, and then a Sheldon Travelling Fellow, at Harvard University during i9i I-I7. As a student he served as Secretary of the Cambridge Entomological Club and Assistant Editor of Psyche. In I9I7 he received a joint appointment in the United States Department of Agriculture and National Museum. In 1925 he fulfilled a lif:-long dream to become a zoo director when he succeeded Alexander Wetmore as head of the National Zoological Park. His autobiographical account ends with his I9I7 appointment, but in fact the entomological odyss:v never ended. As director of the national zoo, Mann made several major expeditions abroad to collect living animals and passed up no opportunity to gather insects, especially his beloved ants and ant-guests, on the side. Those privileged to know him in his later years could still sense the full ex- 
citement of this continuing adventure in his wondrous after-dinner anecdotes of field trips around the world. A common story has it that Mann's faculty sponsor at Harvard, William Morton Wheeler, was at first keenly disappointed when he abandoned a full-time career as entomologist for zoo-keeping but soon became completely reconciled by his former student's obvious genius in the latter role. At the National Zoological Park, Mann was enormously successful. He developed humane, new techniques in zoo culture and was responsible for the introduction of many new animals to zoo life. He was renowned for the wit and eloquence with which he sought, and successfully obtained, the congressional appropriations needed to expand his zoo. His unfailing hospitality was extended to persons from all walks of life, and he had many close friends and an army of warm personal admirers. "Small in stature, puckish, bright-eyed and almost formally unkempt, Dr. Mann possessed a gentle wit which he used sparingly in public - lest it be considered unseemly in a scientist of his acknowledged standing. . . He became a familiar figure to thousands of Zoo patrons who brought away with them the charming memory of intimate little chats he was never too busy to hold with the least of his visitors."* When he died in his Washington home on October ro, I960, at the age of seventy-four, the Ant Hill Odyssey perhaps seemed to many of his friends no more than a remote chapter in a colorful past. Yet it should not be forgotten that his early work produced major contributions that have actually gained in value with the passage of time.

Mann's collections of ants and myrmecophiles, which are the most significant parts of his general collections, are divided chiefly between the Museum of Comparative Zoology and the U.S. National Museum. His entomological publications are based mostly on this material, a fact that gives them their exceptional value. Mann's collections, especially those of ants made in the West Indies and South Pacific, were unusually thorough. Few men have been able to write taxonomic papers on tropical insect faunas with such an intimate firsthand knowledge of the ecology and faunal relationships of his study material. As a result, his larger monographs have been little improved on by later work and will undoubtedly remain primary references for years to come. The following bibliography includes as complete a list of Mann's technical entomological publications as could be assembled at this time. References to his well-known popular article on ants in the National Geographic and to his autobiography are also included.

*The Washington Post, October 11, 1960. 
No attempt has been made to list his articles dealing with zoo culture, travel, and other popular topics.

E. O. Wilson

\section{Entomological Publications of William M. ManN}

I9I I

Notes on the guests of some Californian ants. Psyche, $I 8($ I $): 27-31$.

On some northwestern ants and their guests. Psyche, $18(3)$ :IO2I09.

I9I2

A third collection of Mallophaga from Alaskan birds. Ent. News, 23:12-I 7. (With V. L. Kellogg).

Mallophaga from islands off Lower California. Ent. News, 23:5665. (With V. L. Kellogg).

Parabiosis in Brazilian ants. Psyche, $I 9(2): 36-4 \mathrm{I}$.

Note on a guest of Eciton hamatum Fabr. Psyche, Ig(3) :98-IoO.

List of Histeridae and Buprestidae (Stanford Expedition to Brazil, I9I I). Psyche, Ig(4):Ir 8-I2I.

A protective adaptation in a Brazilian membracid. Psyche, I9 (5): I 45-I 47 .

Literature for I9I I on the behavior of ants and myrmecophiles. J. Animal Behavior, $2(6): 400-420$.

1913

Literature for I9I2 on the behavior of ants and myrmecophiles. J. Animal Behavior, 3(6) :429-445.

Mallophaga from Brazilian birds. Psyche, 20 ( I) : I 5-23. (With J. H. Paine).

I9I 4

Some myrmecophilous insects from Mexico. Psyche, 2I (5) :I 72I 84 .

The ants of Haiti. Bull. Amer. Mus. Nat. Hist., 33 ( I) :I-6I. (With W. M. Wheeler). 
I9I 5

A new form of a southern ant from Naushon Island, Massachusetts. Psyche, 22(2):5I.

A cursorial tick. Psyche, $22(2): 60$.

Some myrmecophilous insects from Hayti. Psyche, $22(5):$ I6I-I66. I 8 o.

A gynandromorphous mutillid from Montana. Psyche, 22(5):I78-

I9I6

The ants of Brazil (Stanford Expedition to Brazil, I9I I). Bull. Mus. Comp. Zool. Harv., 6o ( I I ) :399-490, 7 plates.

The ants of the Phillips Expedition to Palestine during 19I4. Bull. Mus. Comp. Zool. Harv., 6o (5) : I67-I 74. (with W. M. Wheeler). I91 8

Myrmecophilous insects from Cuba. Psyche, 25(5):IO4-Io6. I9I9

The ants of the British Solomon Islands. Bull. Mus. Comp. Zool. Harv., 63 (7) :273-391, 2 plates.

I920

A proctotrypid inquiline with Formica exsectoides Forel (Hym.). Proc. Ent. Soc. Wash., 22 (3) :59-6o.

Ant guests from Fiji and the British Solomon Islands. Ann. Ent. Soc. Amer., I3 ( I) :60-69.

Additions to the ant fauna of the West Indies and Central America. Bull. Amer. Mus. Nat. Hist., 42 (8) :403-439.

$$
\text { I92 I }
$$

The ants of the Fiji Islands. Bull. Mus. Comp. Zool. Harv., 64 (5) :401-499.

A new genus of termite guest from Fiji. Psyche, 28(2):54-56.

Three new myrmecophilous beetles. Proc. U.S. Nat. Mus., 59: 547-552.

1922

Notes on a collection of West African myrmecophiles. Bull. Amer. Mus. Nat. Hist., $45: 623-630$.

Ants from Honduras and Guatemala. Proc. U. S. Nat. Mus., 6I (I3) :I-54.

1923

New genera and species of termitophilous Coleoptera from northern South America. Zoologica, 3 ( I 7 ) : 323-366. 
Two new ants from Bolivia. Psyche, 30 ( I ) :13-18.

Two serphoid guests of Eciton (Hym.). Proc. Ent. Soc. Wash., 25(9) :I 81-I 82 .

A singular habit of sawfly larvae. Psyche, $30(\mathrm{I})$ :9-13. (With W. M. Wheeler).

1924

Myrmecophiles from the Western United States and Lower California. Ann. Ent. Soc. Amer., I7 ( I ) :87-95.

Notes on Cuban ants. Psyche, $3 I$ (I) :19-2,3.

I 925

Ants collected by the University of Iowa Fiji-New Zealand Expedition. Iowa Studies in Natural History, II (4) :5-6.

Guests of Eciton hamatum (Fabr.) collected by Professor W. M. Wheeler. Psyche, 32 (3) : I66-I 77.

New beetle guests of army ants. J. Wash. Acad. Sci., I5 (4) :73-77.

1926

Some new Neotropical ants. Psyche, 33(4-5) :97-I07.

Three new termitophilous beetles from British Guiana. Proc. Ent. Soc. Wash., $28(7)$ : I 5 I-I 55.

New Neotropical myrmecophiles. J. Wash. Acad. Sci., I6( I6) : 448-455.

I 928

A new Microdon from Panama. Psyche, 35 (3) : 168-ı 70.

1929

Notes on Cuban ants of the genus Macromischa (Hymenoptera : Formicidae). Proc. Ent. Soc. Wash., 3I(8) :I6I-I66.

I 93 I

A new ant from Porto Rico. J. Wash. Acad. Sci., 2 I ( I 7 ) :440-44 I. I 934

Stalking ants, savage and civilized. National Geographic Mag., 66 (2) :I 7 I-I 92.

1935

Two new ants collected in quarantine. Psyche, 42 ( I ) :35-37.

1948

Ant Hill Odyssey. Little, Brown. (Autobiography). 


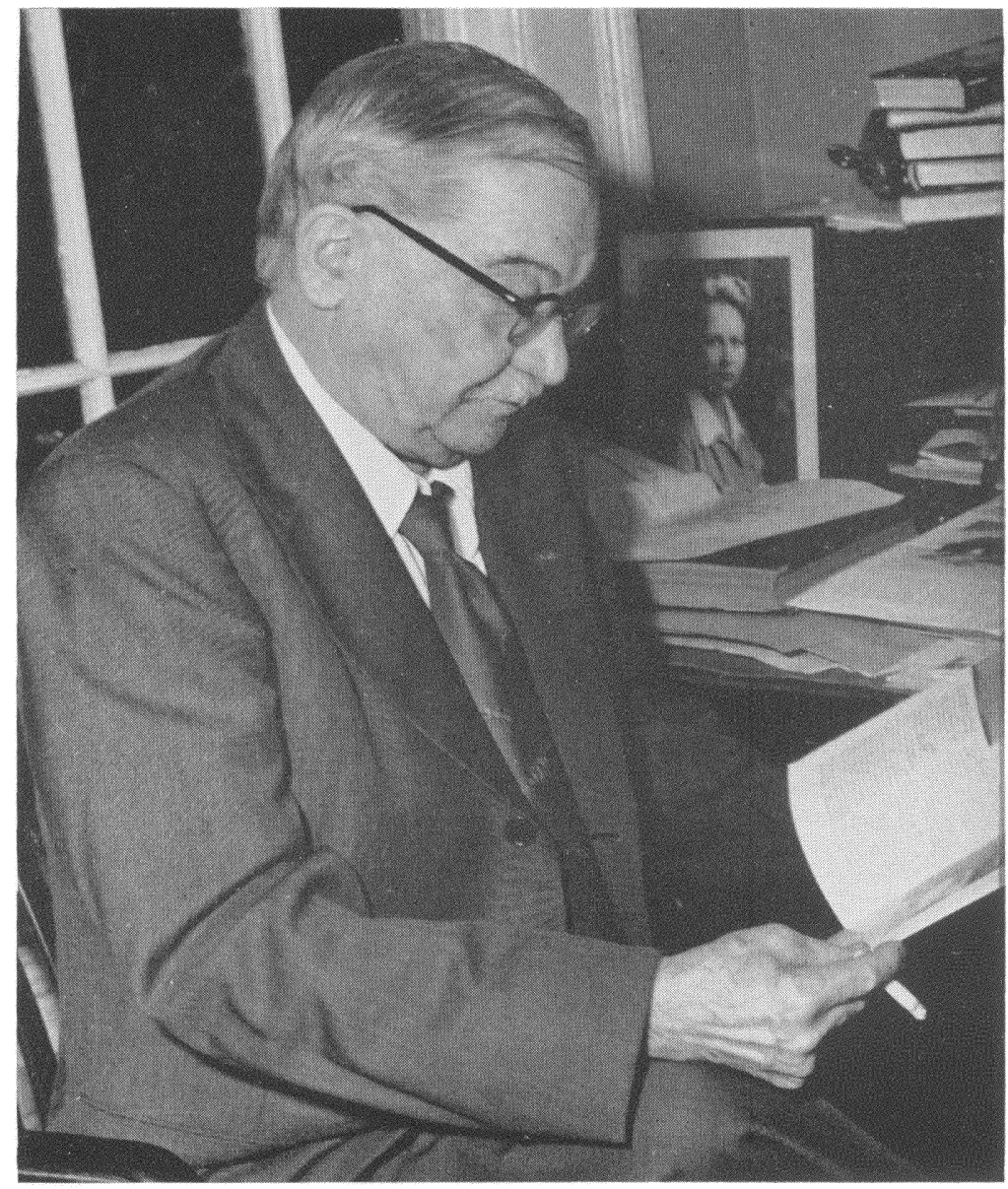

William M. ManN

i 886- 1960

From a photograph taken in October, 1956. Courtesy of the Smithsonian Institution and Mrs. Lucile Q. Mann. 

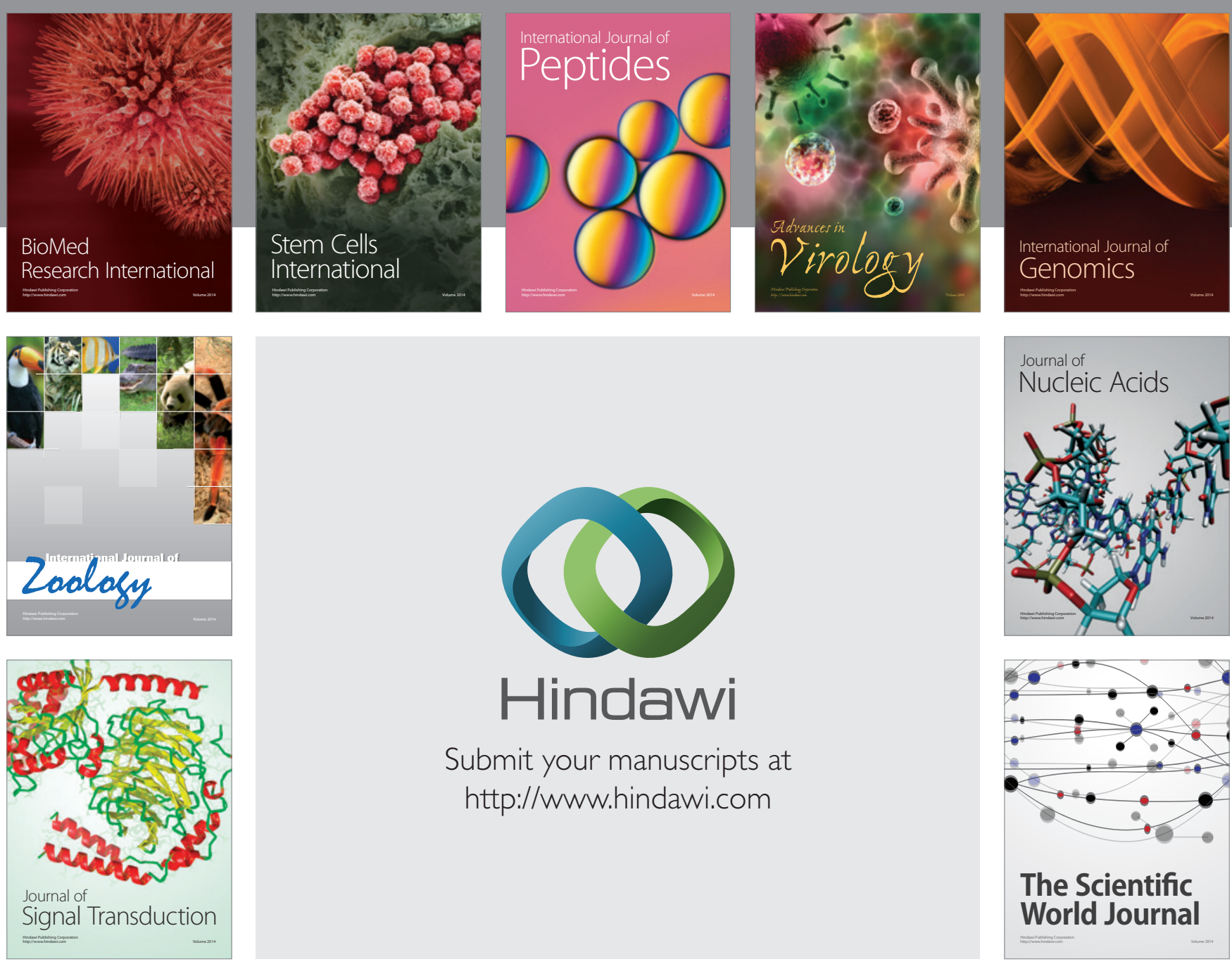

Submit your manuscripts at

http://www.hindawi.com
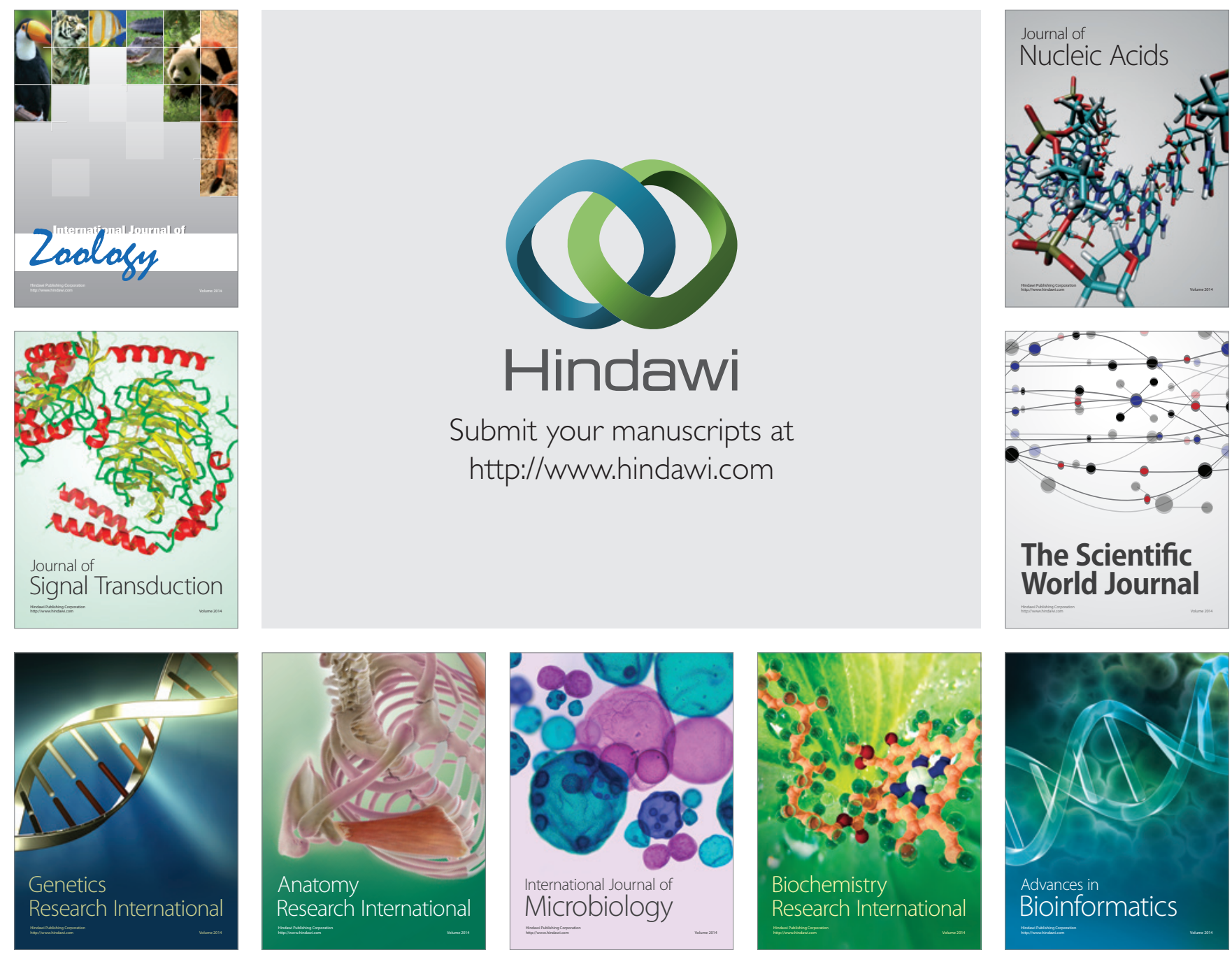

The Scientific World Journal
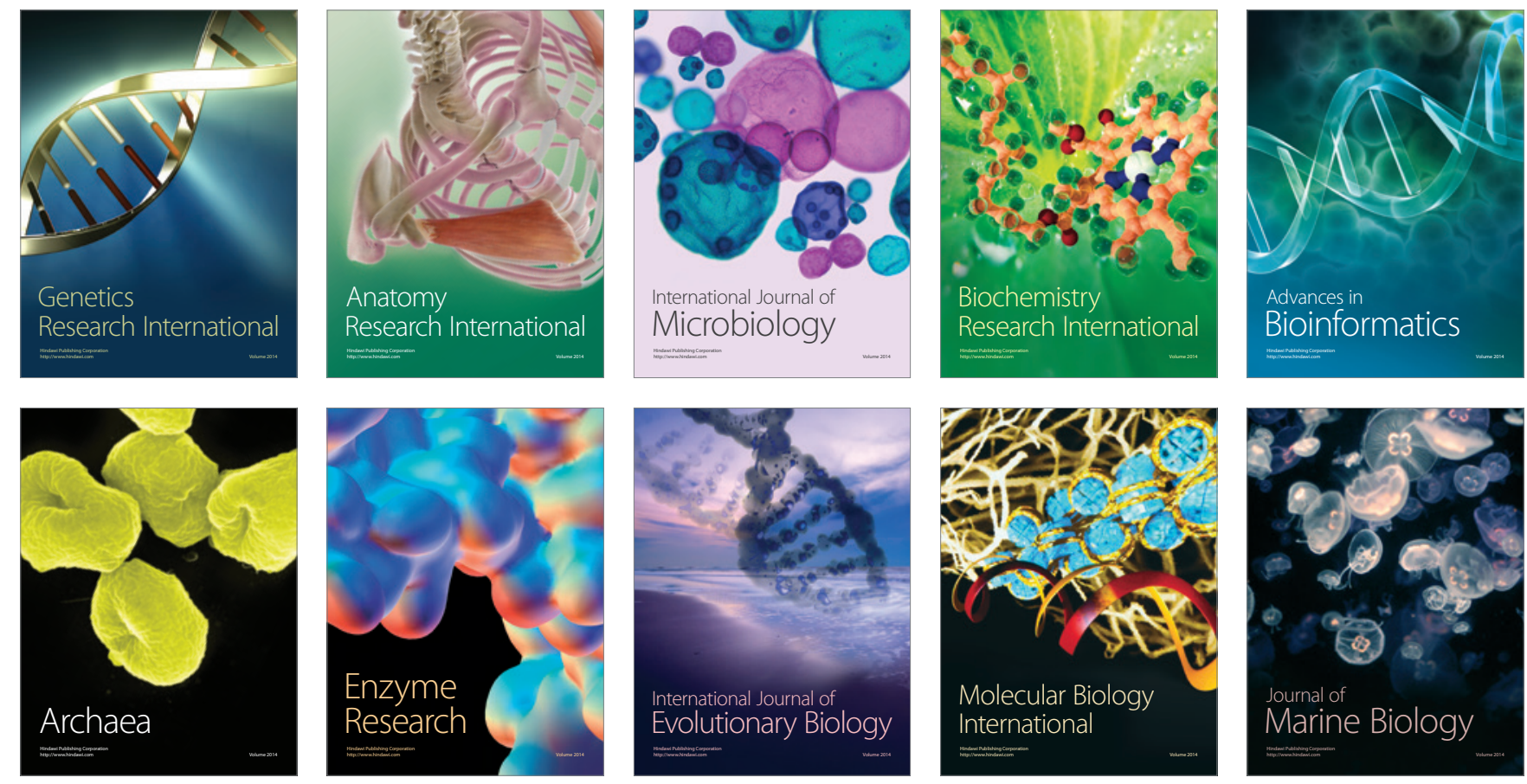